\title{
"Think I shall like these tropics": D. H. Lawrence and Edward, Prince of Wales, in Sri Lanka in 1922
}

\author{
Richard Lansdown \\ James Cook University
}

\begin{abstract}
$A^{p}$ part from translating some short stories by the Sicilian novelist Giovanni Verga, D. H. Lawrence produced only one literary work during or relating to his five weeks' stay in the tropics - at Ceylon, modern-day Sri Lanka — between 13 March and 24 April, 1922. It is one of Lawrence's inimitable but Whitmanesque poems about birds, beasts, and flowers, entitled 'Elephant', and whereas it is true that no English poet, not even Robert Burns or John Clare, wrote as well as he did on animals, "Elephant" is about a good deal more than pachyderms. Rather than subject it to any form of literary analysis, I shall instead try to sketch in some of the background to it, including Lawrence's response to the tropics overall. Weirdly, furthermore, his stay in Sri Lanka coincided with a royal visit by the Prince of Wales, the future scapegrace Edward VIII, on whose account a major local religious festival, the Buddhist Perahera elephant procession (which inspired the poem) was shifted from its usual time of celebration. So Lawrence saw some colonialism, some monarchy, and some religion in one fell swoop: and "Elephant" is the outcome of that exposure. In particular, he zeroes in on that strange German motto of the Prince of Wales, the origins of which are lost in obscurity: "Ich dien," "I serve" — which Lawrence ungrammatically reconfigures as "Dient ihr": "have them serve."1
\end{abstract}

As early as September 1921 Lawrence had told his friend, the American artist Earl Brewster, whom he had met in Capri, that "my heart - and my soul are broken in Europe. It's no use, the threads are broken." "I will go east," he went on, "intending ultimately to go west [that is, to America], as soon as I can get a ship" (Roberts, Boulton, \& Mansfield, 2002, p. 90). In mid-October the Brewsters and their daughter left Capri for Kandy, Ceylon, where the Buddhistically inclined Earl planned to study the faith at a monastery attached to the Temple of the Tooth — where the island's greatest religious treasure, an implausibly oversized tooth of the Buddha's, is stored. Something about the East was appealing in terms of getting away, but Lawrence was inherently suspicious of Brewster's enthusiasm. "I have no deep hope," as regards Buddhism, he told him; "I would rather dig a little, and tend a few fruit trees with you, than meditate with you." (Roberts et al., 2002, p. 95) (I should add that the interest in horticulture is entirely in character: Lawrence was intensely domestic and

\footnotetext{
${ }^{1}$ There are two theories about "Ich dien," both nowadays discredited: that Edward the Black Prince, first Prince of Wales (1330-1376) took the motto from the dead King John of Bohemia, after defeating him at the battle of Crécy in 1346; and that, on the contrary, the expression is the Welsh near-

homophone "Eich dyn" ("Your man") and emerges from the same battle, in royal homage to a corps of Welsh archers.
} 
intensely practical throughout his life. He cooked all the meals for himself, his wife Frieda, and any guests they entertained; refused to employ a servant; baked bread and put up shelves. He is surely the only substantial English novelist to make his own marmalade.) Still, he felt like going "really away" (Roberts et al., 2002, p. 96) and Kandy was certainly that, though "my compass needle is a shifty devil" as he admitted (Roberts, et al., 2002, p. 97). "The east seems to me the world to meditate in," he told Brewster in October, "Europe the world to feel in, American the world to act in" (Roberts et al., 2002, p. 103) — so he remained radically unsure.

In November, furthermore, Lawrence received an invitation from a wealthy culturevulture, Mabel Dodge Sterne (soon to be Mabel Dodge Luhan, when she forsook her third husband, a white American one, for her fourth, a Native American), to stay with her and live an artistic existence in Taos, New Mexico. But Lawrence had conceived a dread of the eastern United States, imagining that it would be nothing other than a continuation of European civilization, only even more modern and barbarous. He wanted to approach America through its western seaboard: but this put him at the mercy of the shipping lines out of Naples, almost all of which carried emigrants to New York. There followed six months of characteristic dithering, while he and Frieda sat out their lease in Taormina, Sicily.

Is everybody in Ceylon "as beshitten as here?", Lawrence enquired of Brewster in November. "I'll bet they are." (Roberts et al., 2002, p. 109). "I can't help rather hating Buddha, the cross-legged pigeon" (Roberts et al., 2002, p. 126). But, to cut a long story short, and having told Mabel definitely after Christmas that they had found a boat from Bordeaux to New Orleans (Roberts et al., 2002, p. 152), and then deciding in mid-January that "suddenly that I am on the point of coming to America I feel I can't come" (Roberts et al., 2002, p. 168), Lawrence's "shifty devil" moved again, after a particularly persuasive letter from Brewster, who had settled down in his new location. "Probably there, east, is the source," Lawrence found himself agreeing, "and America is the extreme periphery. Oh God, must one go to the extreme limit, then to come back?" (Roberts et al., 2002, p. 170). "I feel America is unreligious," he wrote to Sterne by way of explanation; "I feel it will give one rest, peace, inside one, this Ceylon" (Roberts et al., 2002, p. 181, p. 180). In the process he fell for the old tropical dream, or one of them at least: "Palm trees and elephants and dark people: incantevole [enchanting]!” (Roberts et al., 2002, p. 194).

So it was that he and Frieda took berths travelling second class on the R. M. S. Osterley, from Naples to Sydney via Ceylon. Of all English writers Lawrence would surely be the one we might assume to be most restless on a cruise; but in fact he hugely enjoyed it - mostly, I imagine, for the same reason many modern housewives dream of cruising: he didn't have to cook. Breakfast was particularly impressive: "stewed pears, porridge, fish, bacon, eggs, fried sausages, beefsteak, kidneys, marmalade - all there," he told his mother-in-law (Roberts et al., 2002, p. 205). He also met many Australians, on their way home from Europe, and was charmed by them. He even did something even more unimaginably un-Lawrencian: he indulged in some mild flirtation with fellow passengers. The experience paradoxically reminded him that "civilisation is a fine and beautiful thing, if only it remains alive, and doesn't become ennuyée" (Roberts et al., 2002, p. 206). He was charmed, too, by the Suez Canal: "Behind lies at last Jerusalem, Greece, Rome and Europe," he wrote in the Red Sea, "fulfilled and past, a great terrible dream" (Roberts et al., 2002, p. 212). As so 
often, to travel in space was to travel in time, and to leave the monotheistic faiths behind, in the Mediterranean.

The Lawrences arrived at Colombo on 13 March, and the novelist clearly experienced the shock visitors from the temperate zone often undergo on arrival in the tropics. Within a week he was writing from Kandy "It is very hot. - Lovely to look at - but I doubt if I shall stay very long in Ceylon." (Roberts et al., 2002, p. 214) On 21 March, two days before he came to this conclusion, the Prince of Wales made landfall in H. M. S. Renown, over half way through a colossal tour of India and the East. Concerns had been raised about the Prince's health before his departure from England, but George V insisted on a high-profile event, to build Imperial morale in the aftermath of the war. Edward arrived in Bombay in mid-November, 1921, and immediately made a good impression, but the itinerary was extensive, even by royal standards: Baroda, Rajasthan, Lucknow, Allahabad, Benares, Nepal, Patna, Calcutta, Rangoon, Madras, Bangalore, Mysore, Hyderabad, Nagpur, Indore, Bhopal, Gwalior, Agra, and Delhi; thence to Patiala and Lahore, Peshawar, the Khyber Pass,

Rawalpindi, and back to Delhi, before sailing from Karachi four months after his arrival. He would end the tour, as it happened, in Tokyo, as the guest of another prince: Hirohito by name.

Depending on whom you believe, Edward was either dog-tired and maladroit, or a triumphant Prince Charming. "He was really tired of all the Empire touring," his companion, Rushbrook Williams, later recorded, "but he faced the Indian tour with his usual sense of duty.... Above all [the King] sanctioned a programme which was much too heavy; we all of us, let alone HRH, were almost dead by exhaustion by the end of it." (Donaldson, 1974, p. 96) It seems he was too informal - and too much given to the cocktail shaker - to impress the Indians. "Melancholy by nature and easily bored," his biographer comments,

when he was forced to appear at public functions which did not interest him, by his unresponsiveness and air of discontent, he gave colour to the kind of rumour that he was "still suffering from a hangover from the night before" or "was drunk at the time", while his passing flirtations were given more importance by offended civil servants and their wives than possibly...they deserved. (Donaldson, 1974, p. 98)

In his official account, The Prince of Wales' Eastern Book, lavishly illustrated with both watercolours and photographs, Sir Percival Phillips was naturally more upbeat, particularly as concerned the four-day visit to Ceylon: a land "wholly friendly and loyal," where "admiring natives" "waited hours in the sun to see him for five minutes." All this "was a welcome change from the set processions of the Indian tour," and the Prince was in his element, apparently, waving from limousines, greeting ex-servicemen, and inspecting the Buddha's tooth with the requisite amount of polite interest (Anon, 1922).

The highlight of Edward's visit - and, it turned out, of Lawrence's, too - was the Perahera procession of 100 sacred elephants, one carrying the sacred tooth, which took place on 23 March. Certainly what he saw of the Prince at the event was not encouraging: 
Poor devil, he is so thin and nervy: all twitchy: and seems worn out and disheartened. No wonder, badgered about like a doll among a mob of children. A woman threw a bouquet, and he nearly jumped out of his skin. (Roberts et al., 2002, p. 215)

The Prince, Lawrence recorded a week later, "seemed sad and forlorn," "almost the butt of everybody." "They all secretly hate him for being a Prince, and make a Princely butt of him - and he knows it. My sympathy," Lawrence unexpectedly concluded, "was with him." (Roberts et al., 2002, p. 218.) The fundamental passivity of the "Ich Dien" pledge and undertaking brought out Lawrence's current fascination with the nature of political leadership and its relation to masculinity. "The responsibility for England, the living England," he told a correspondent, "rests on men like you and me...probably even the Prince of Wales," whereas Ceylon "seems sort of unmanly" (Roberts et al., 2002, p. 219-20). "I don't believe in either liberty or democracy," he wrote:

I believe in actual, sacred, inspired authority: divine right of natural kings: I believe in the divine right of natural aristocracy, the right, the sacred duty to wield undisputed authority. (Roberts et al., 2002, p. 226)

How much inspired authority was visible in the diffident heir apparent it is hard to tell; certainly Lawrence seems to be seeing something hardly there in the "worn out and disheartened" royal tourist.

"But the Perahera," Lawrence recorded, "was wonderful"; and his prose typically rose up to meet it:

it was night, and flaming torches of cocoanut blazing, and the great elephants in their trappings, about a hundred, and the dancers with tomtoms and bagpipes, and half naked and jeweled, then the Kandyan chiefs in their costumes, and more dancers, and more elephants, and more chiefs, and more dancers, so wild and strange and perfectly fascinating, heaving along by the flames of torches in the hot, still, starry night. Afterwards, fireworks over the lake, and thousands and thousands of natives, so that it looked like some queer dream when the fire flared up and showed their thousands of dark faces and white wraps packed on the banks. (Roberts et al., 2002, p. 215-16)

All this "made an enormous impression on me - a glimpse of the world before the Flood. I can't get back into history - The soft, moist, elephantine pre-historic has sort of swamped over my known world" (Roberts et al., 2002, p. 234). "One realizes," he noted, "how very barbaric the substratum of Buddhism is. I shrewdly suspect that the high-flownness of Buddhism [which Earl Brewster certainly manifested] altogether exists mostly on paper" (Roberts et al., 2002, p. 218). "I feel absolutely dead off Buddhism, either Nibbana or Nirvana, Kania or Karma. They can have Buddha." (Roberts et al., 2002, p. 218.) "In later years," Earl Brewster recalled in 1934, after Lawrence's death, "he used often to say of the seated Buddha: 'Oh I wish he would stand up!'” (Brewster \& Brewster, 1934, p. 49). Certainly he refused to visit Buddhist temples, waiting outside "standing in his shoes, hat tight on his head, declaring that it was no use" (Brewster \& Brewster, 1934, p. 261). 
The tropical landscape was problematic and memorable in similar proportions. He disliked what he called its "boneless suavity," "and the thick, choky feel of tropical forest, and the metallic sense of palms and the horrid noises of the birds and creatures, who hammer and clang and rattle and cackle and explode all the livelong day, and run little machines all the livelong night." "Birds shriek and pop and cackle out of the jungle, creatures jerk and bounce about" (Roberts et al., 2002, p. 221). Earl Brewster's wife Achsah recalled that night time wildlife was distinctly audible through the skylights of the house they shared: "not only could we hear mortal conflicts over our heads, but could see the wild-cats through the glass on the roof.... In the morning often there would be a trail of blood where a wounded snake had dragged his length" (Brewster \& Brewster, 1934, p. 251). One morning Lawrence was horrified to find a family of rats camping in his solar topee. Crashing coconut fronds made the little group all jump in fear at night, and mildew began to infest their clothing. The scents "make me feel sick, the perpetual nauseous overtone of cocoanut and cocoanut fibre and oil, the sort of tropical sweetness which to me suggests an undertang of blood, hot blood, and thin sweat" (Roberts et al., 2002, p. 225). He couldn't work, and he disliked the food: "my inside [meaning his bowels rather than his lungs] has never hurt me so much in all my 36 years as in these three weeks" (Roberts et al., 2002, p. 224). He grew ridiculously paranoid, speculating as to whether the servants were discussing murdering them. "Europe is, I fancy," he wrote in an abrupt volte-face, "the most satisfactory place in the end" (Roberts et al., 2002, p. 222). But clearly the tropical environment also sank in. Years later Richard Aldington, author of Portrait of a Genius, But..., remembered Lawrence asking him "if I had heard the night noises of a tropical jungle, and then instantly emitted a frightening series of yells, squawks, trills, howls, and animal 'help-murder' shrieks." "Only when living in the tropics myself," Aldington concluded, "did I realise that he had accomplished the seemingly impossible task of remembering and being able to imitate all that medley of fantastic noises." (Aldington, 1950, p. 248.)

Perhaps I have made Lawrence sound somewhat ingracious in his attitude to the tropics in general and to Buddhism in particular. He was, it is true, as quick to reject things as he was to experiment with them, as he himself understood. 'I'm determined to try the South Sea Isles," he wrote on his way from Sri Lanka to Australia: "Don't expect to catch on there either. But I love trying things and discovering how I hate them." And he concluded of his brief visit to Ceylon: "Yet it is now a very precious memory, invaluable. Not wild horses would drag me back. But neither time nor eternity will take away what I have of it" (Roberts et al., 2002, p. 239). In an essay called "New Mexico," written in 1928, two years before his death, Lawrence lamented modern humanity's relation to the world. "Superficially," he wrote, "the world has become small and known. Poor little globe of earth, the tourist trots round you as easily as they trot round the Bois [du Boulogne] or round Central Park. There is no mystery left, we've been there, we've seen it, we know all about it. We've done the globe, and globe is done." And he admitted that his experience in "holy Kandy, in Ceylon, the holy of holies of southern Buddhism, had not touched the great psyche of materialism and idealism which dominated me," which would only be broken up in him by New Mexico (Lawrence, Mornings in Mexico, p. 175-6). But still:

I had seen what I felt was a hint of wild religion in the so-called devil dances of a group of naked villagers from the far-remote jungle in Ceylon, dancing at midnight under the torches, glittering wet with sweat on their dark bodies as if they had been 
gilded, at the celebration of the Pera-hera in Kandy, given to the Prince of Wales. And the utter dark absorption of these naked men, as they danced with their knees wide apart, suddenly affected me with a sense of religion, I felt religion for a moment. For religion is an experience, an uncontrollable, sensual experience even more so than love: I use sensual to mean an experience deep down in the senses, inexplicable and inscrutable. (Lawrence, Mornings in Mexico, p. 178)

The "Pale, dispirited Prince" of "Elephant," with "his chin on his hands, his nerves tired out" (Lawrence, Poems, p. 340), could not undergo such an experience. Nor could he possibly comprehend that the native population missed the days when the King of Kandy would himself process among the 100 elephants: "the simple country man expects to see his lord in all the glory of jewels and cloth of gold," as a contributor to National Geographic wrote in 1932 (Burroughs, 1932, p. 99); "He makes the journey to Kandy only once a year, and on that day wants to see the parades as his father saw them." That "inexplicable and inscrutable" desire, that bound the country man of Ceylon in service to his monarch and his religion ("ich dien" in that sense), no longer invested the Prince of Wales; but Lawrence believed he could see it flickering in the crowds that trooped past the royal visitor on his dais:

I wish some dark-faced man could have taken the feathers three

And fearless gone up the pavilion, in that pepper-box aloft and alone

Held the three feathers out on the night, with a dark, fierce hand above the host, Saying softly: Dient ihr! Dient!

Omnes, vos omnes, servite.

Serve me, I am meet to be served.

Being royal of the gods. (Lawrence, Poems, p. 343)

In the poem's original draft Lawrence wrote: "I wish they had given the three feathers to $m e$; That I had been he in the pavilion, as in a pepper-box aloft and alone/To stand and hold feathers, three feathers above the world" (Lawrence, Poems, p. 1057; italics added). Perhaps in revising the poem he came to realize that the world he ruled was one of the imagination rather than reality; certainly his reign there has proved longer than Edward's.

\section{Works Cited}

Anon, Sir P.P. (1922). The Prince of Wales' Eastern Book: A Pictorial Record of the Voyages of H. M. S. "Renown” 1921-1922. London: Hodder and Stoughton..

Aldington, R. (1950). D. H. Lawrence: Portrait of a Genius, But.... London: Heinemann.

Brewster, E. \& Brewster, A. (1934). D. H. Lawrence: Reminiscences and Correspondence. London: Secker and Warburg.

Burroughs, G. H. G. (1932). The Perahera Processions of Ceylon. National Geographic, 62(1), 90-100. 
Donaldson, F. (1974). Edward VIII. London: Weidenfeld and Nicolson.

Lawrence, D. H. (2009). Mornings and Mexico and Other Essays. Edited by V.C. Hyde. Cambridge: Cambridge University Press.

Lawrence, D. H. (2013). The Poems. Edited by C. Pollnitz. Cambridge: Cambridge University Press.

Roberts, W., Boulton, J.T., \& Mansfield, E. (Eds.). (2002). The Letters of D. H. Lawrence, Volume Four: June 1921-May 1924. Cambridge: Cambridge University Press. 